\title{
Virulence of entomopathogenic nematodes (Rhabditida: Steinernematidae, Heterorhabditidae) to spittlebug Mahanarva spectabilis (Hemiptera: Cercopidae)
}

\author{
Virulência de nematoides entomopatogênicos (Rhabditida: Steinernematidae, \\ Heterorhabditidae) para cigarrinha-das-pastagens Mahanarva spectabilis \\ (Hemiptera: Cercopidae)
}

\author{
Elder Simões de Paula Batista ${ }^{1 *}$, Alexander Machado Auad ${ }^{2}$, Vanessa Andaló ${ }^{3}$, \\ Caio Márcio de Oliveira Monteiro ${ }^{4}$
}

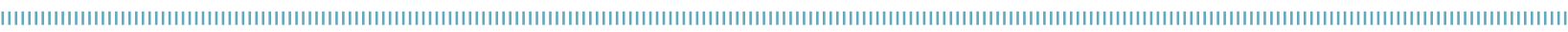

\begin{abstract}
The spittlebug can seriously limit the production of forage, and the use of chemical products to control insect pests is costly and can harm the environment. Thus, there is a need to reduce the reliance on chemical agents by developing new strategies. The virulence of nine strains of entomopathogenic nematodes (EPNs) to spittlebugs was investigated under laboratory and greenhouse conditions. Fourth/fifth-instar nymphs of Mahanarva spectabilis were exposed to EPNs in the laboratory and the most virulent strains were applied on the nymphs in the greenhouse at concentrations of 2,000 and 4,000 EPNs/mL. The efficacy of the pathogenic agent was confirmed by the dissection of dead hosts. All the tested strains were pathogenic to the M. spectabilis nymphs in laboratory, particularly Steinernema carpocapsae, S. feltiae, S. riobrave and Heterorhabditis amazonensis RSC1, each of which caused nymph mortality higher than $80 \%$. The concentration did not influence the efficiency of the strains, and those selected in the laboratory had similar efficiency in the greenhouse, except for $S$. carpocapsae, which was not as effective as the others. Entomopathogenic nematodes can be included in integrated pest management programs to M. spectabilis.
\end{abstract}

KEYWORDS: microbial control; Heterorhabditis; pastures; Steinernema.

\begin{abstract}
RESUMO: A cigarrinha-das-pastagens pode causar sérias limitaçôes na produção de forragens, e o uso de produtos químicos para o controle é caro, além de poder prejudicar o ambiente. Entáo, existe a necessidade de reduzir o uso de agentes químicos através do desenvolvimento de novas estratégias de controle dessa praga. A virulência de nove isolados de nematoides entomopatogênicos (NEPs) sobre a cigarrinha-das-pastagens foi avaliada em condiçóes de laboratório e casa-de-vegetação. Ninfas de quarto/quinto ínstar de Mahanarva spectabilis foram expostas aos isolados de NEPs em laboratório, e os mais virulentos foram aplicados sobre as ninfas em casa-de-vegetação sob as concentrações de 2000 e $4000 \mathrm{JIs} / \mathrm{mL}$. A eficácia do agente patogênico foi confirmada pela dissecação dos hospedeiros mortos. Todos os isolados testados foram patogênicos às ninfas da cigarrinha-das-pastagens em laboratório, particularmente Steinernema carpocapsae, S. feltiae, S. riobrave e Heterorhabditis amazonensis RSC1, cada um deles causando mortalidade maior que $80 \%$. A concentração não influenciou a eficiência, exceto para S. carpocapsae, o qual náo foi táo efetivo como os demais em casa-de-vegetação. Nematoides entomopatogênicos podem ser incluídos em programas de manejo integrado de $M$. spectabilis.
\end{abstract}

PALAVRAS-CHAVE: controle microbiano; Heterorhabditis; pastagem; Steinernema.

'Departamento de Fitossanidade; Universidade Estadual Paulista “Júlio de Mesquita Filho" (UNESP) - Jaboticabal (SP), Brazil.

'Laboratório de Entomologia da Embrapa Gado de Leite - Juiz de Fora (MG), Brazil.

${ }^{3}$ Laboratório de Patologia de Insetos; Universidade Federal de Lavras (UFLA) - Lavras (MG), Brazil.

${ }^{4}$ Pós-graduação em Ciências Veterinária; Universidade Federal Rural do Rio de Janeiro - Seropédica (RJ), Brazil.

*Corresponding author: elderspb@gmail.com

Received on: 07/11/2012. Accepted on: 13/12/2013. 


\section{INTRODUCTION}

The spittlebug Mahanarva spectabilis (Distant, 1909) (Hemiptera: Cercopidae) can seriously limit forage production, and according to Holmann; Peck (2002), the production of meat or milk by cattle left to graze in pastures heavily infested with spittlebugs $\left(50\right.$ adults $\left./ \mathrm{m}^{2}\right)$ can decrease up to $54 \%$, and the production cost can increase up to $30 \%$ because of this infestation level.

The use of chemical products to control insect pests is costly and can harm the environment. Thus, there is the need to reduce the reliance on chemical agents by developing integrated pest management programs. As part of this effort, attention has been focused on developing forage grasses that are resistant to spittlebugs (AUAD et al., 2007) and for the use of biological control agents. Among these agents, entomopathogenic fungi are among the most studied ones, as mentioned by Tiago et al. (2011), being used against spittlebugs.

Entomopathogenic nematodes (EPNs) are among the most promising potential biological control agent,because of the speed with which they kill the host, the facility of mass producing them at low cost and the broad spectrum of susceptible hosts (Georgis et al., 2006). Additionally, they can be used together with other measures, including the application of chemical products (Koppenhöfer et al., 2002; ReIs-MeNini et al., 2008). EPNs also have the ability to find hosts that have cryptic habits (KaYA; GAUGLER, 1993), such as spittlebugs.

Entomopathogenic nematodes have been shown to be efficient against various agricultural pests (GREWAL et al., 2001), like pests of protected crops, such as Bradysia mabiusi (Lane, 1959) (Leite et al., 2007), the boll weevil Anthonomus grandis Boheman, 1843 (CaBANILlas, 2003), and stored grain pests, like Tribolium castaneum (Herbst, 1797) and Plodia interpunctella (Hübner, 1813) (RAmos-Rodríguez et al., 2007), besides animal ectoparasites (Monteiro et al., 2010; SiLVA et al., 2012). Few papers have been published concerning the use of nematodes to control cercopids; three of them analyzed Mahanarva fimbriolata (Stal, 1854) (Leite et al., 2002; Leite et al., 2005; Batista et al., 2011) and one studied $M$. spectabilis as the target pest (BATISTA; AuAd, 2010).

Because of the scarce knowledge about the efficiency of EPNs against spittlebugs, the aim of this study was to ascertain the pathogenicity and virulence of different concentrations and strains of EPNs on M. spectabilis nymphs in laboratory and greenhouse conditions.

\section{MATERIAL AND METHODS}

Elephant grass plants (Pennisetum purpureum Schumacher) cv. Pioneiro used in the greenhouse tests came from the experimental field. Single-node seedlings were planted in $500 \mathrm{~mL}$ disposable plastic cups in a substrate of earth/manure (1:1) and kept in a greenhouse under twice-daily spraying water.

The used nematodes had been previously bred according to the method proposed by KaYA; STOCK (1997) and White (1927), employing larvae of Tenebrio molitor (Linnaeus, 1758) as host. The nematode species/strains were: Steinernema anomali (Kozodoi, 1984); S. carpocapsae (Weiser, 1955); S. feltiae (Filipjev, 1934); S. riobrave Cabanillas, Poinar and Raulston, 1994; Heterorhabditis amazonensis RSC1 Andaló, Nguyen and Moino Jr, 2006; H. amazonensis RSC5; Heterorhabditis sp. JPM3; Heterorhabditis indica LPP1 Poinar, Karunakar and David, 1992; and Heterorhabditis sp. Piauí.

The nymphs came from the breeding stock maintained by the Entomology Laboratory of Embrapa Dairy Cattle. To obtain the nymphs, adults were collected in a signal grass field and placed in a greenhouse, where they mated, laid eggs and the nymphs were fed and developed on elephant grass and signal grass as hosts, until they reached the stage used in the trials.

Because of the difficulty to distinguish between instars, we used nymphs of the fourth and/or fifth instar, since these are the last stages of immature development, in which individuals are more vigorous and can produce more froth, providing more protection.

Five nymphs were placed in each Petri dish $(9 \mathrm{~cm})$ lined with filter paper, and then $1 \mathrm{~mL}$ of an aqueous suspension of 2,000 infective juveniles/ $\mathrm{mL}$ of each EPN strain was applied separately, as well as $1 \mathrm{~mL}$ of distilled water, according to the routine employed by LeITE et al. (2005), therefore forming nine treatments (strains) with ten repetitions each (totaling 50 nymphs per treatment), along with one control group to make sure that nymphs were free from previous contact with nematodes and that deaths occurred exclusively because of the treatments. The dishes were then closed with plastic film and stored in a climate-controlled chamber at $25^{\circ} \mathrm{C}, 70 \%$ $\mathrm{RH}$ and 12-hour photophase. After seven days of exposure, dead nymphs were dissected and the hemolymph of each one was observed under a stereoscopic microscope. When nematodes in different stages of development were detected, we considered they were the cause of death.

The data were submitted to analysis of variance, and means were compared by the Tukey test, with 5\% significance, using the SAS statistical program (version 9.2).

In the second experiment, one nymph of the fourth or fifth instar was placed at the base of an elephant grass seedling in a plastic cup, with the roots previously exposed, being kept in a greenhouse at an average temperature of $21.5^{\circ} \mathrm{C}$ and relative humidity of $94 \%$. After 24 hours, when the nymphs were already protected by froth, the nematodes that presented pathogenicity higher than $80 \%$ in the laboratory tests were applied in two concentrations $(2,000$ and $4,000 \mathrm{IJ} / \mathrm{mL})$ in a total volume of $2 \mathrm{~mL}$ per cup, through a sprinkler nozzle, with the stream addressed to the froth. 
Therefore, the experimental setup was a factorial scheme with four strains and two concentrations, in a total of eight treatments and seven repetitions, besides one control group with seven repetitions to confirm that the substrate was free of nematodes, and, hence, that the deaths were caused by the treatments. Nymphs were monitored daily and, as in the laboratory tests, the dead ones were dissected and every hemolymph was observed under a stereoscopic microscope to detect the presence of nematodes. When they were present, they were considered as the cause of death.

The effect of the strains and concentrations was again submitted to the analysis of variance, and means were compared by the Tukey test with $5 \%$ significance, using the SAS statistical program (version 9.2).

\section{RESULTS AND DISCUSSION}

In the laboratory test, all the species/strains led to the mortality of M. spectabilis nymphs $(\mathrm{p}<0.05)$. The most virulent ones were $S$. riobrave and $S$. feltiae, both causing mortality rates of $92 \%$. Heterorhabditis amazonensis RSC1, S. carpocapsae, S. anomali and Heterorhabditis sp. JPM3 were statistically similar to that, with rates of $80,79,76$ and $68 \%$, respectively. The other nematode species/strain had lower virulence, with $H$. indica LPP1 reaching 56\%, similarly to superior and inferior strains, followed by H. amazonensis RSC5 (48\%) and Heterorhabditis sp. PI (40\%). In all cases, the results differed $(\mathrm{p}<0.01)$ from that of the control group (Fig. 1).

Leite et al. (2005), by evaluating the use of some EPN strains against the root spittlebug $M$. fimbriolata, applied $2,000 \mathrm{IJ} / \mathrm{mL}$ on nymphs of the fifth instar in Petri dishes and found virulence of 100, 98 and $96 \%$ for the strains Heterorhabditis sp. (CB-n5), Steinernema sp. (CB-n6) and Heterorhabditis sp. (CCA), respectively. This is slightly different from our findings, in which species of the Heterorhabditis genus caused a maximum mortality rate of $80 \%$, although the strain responsible to this virulence, (H. amazonensis RSC1), was among the most virulent ones. Similar results were expected, since the two species of spittlebugs are very similar in terms of behavior, physiology and anatomy.

We observed that $H$. amazonensis RSC5 and $H$. amazonensis RSC1, on one hand, and Heterorhabditis sp. JPM3 and Heterorhabditis sp. PI on the other, presented different levels of pathogenicity. Similar variations were observed by CABANILLAS (2003), in which two strains of $S$. riobrave (TX and $355^{\mathrm{d}}$ ) and three of H. bacteriophora (IN, HbL and HP88) had different levels of pathogenicity and lethal concentrations against Anthonomus grandis. MAULÉON et al. (1993) also observed differences among strains of $S$. carpocapsae (All, Breton and DD136) concerning the lethal period against Boophilus annulatus. Although the three strains belong to the same species,

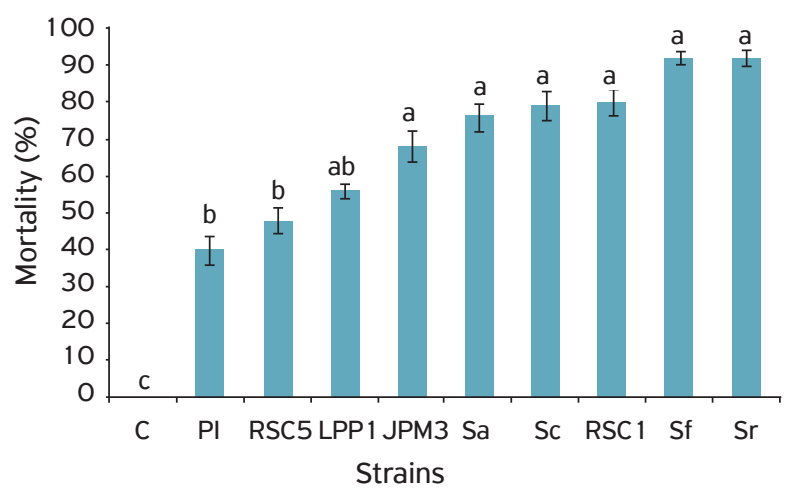

Bars followed by different letters differ from each other by the Tukey test $(p<0.05)$.

C: control; PI: Heterorhabditis sp. PI; RSC5: H. amazonensis RSC5; LPP 1: H. indica LPP 1; JPM3: Heterorhabditis sp. JPM3; Sa: Steinernema anomali; Sc: S. carpocapsae; RSC 1: H. amazonensis RSC1; Sf: S. feltiae; Sr: S. riobrave.

Figure 1. Mortality \pm standard error caused by strains of entomopathogenic nematodes to Mahanarva spectabilis nymphs at a concentration of $2,000 \mathrm{IJs} / \mathrm{mL}$ under laboratory conditions.

the explanation for this difference is the distinction in their behavior in relation to emergence, foraging strategy and search for hosts, along with the physiological differences and changing tolerance to abiotic factors that occurs among the several EPN strains (LewIs et al., 2006).

From the results of laboratory experiments, we chose S. riobrave, S. feltiae, $H$. amazonensis $\mathrm{RSC} 1$ and $S$. carpocapsae for testing in the greenhouse pot trials.

In this trial, all of the strains, at both concentrations (2,000 and 4,000 IJs/mL), were pathogenic to M. spectabilis nymphs, with $S$. riobrave at $2,000 \mathrm{IJ} / \mathrm{mL}$ being the most virulent one, causing $71.43 \%$ of mortality, followed by $H$. amazonensis RSC1 (2,000 IJ $/ \mathrm{mL})$, S. feltiae (4,000 IJ $/ \mathrm{mL}), H$. amazonensis RSC1 $(4,000 \mathrm{IJ} / \mathrm{mL})$ and $S$. riobrave $(4,000 \mathrm{IJ} / \mathrm{mL})$, all of which caused $57.14 \%$ of mortality. Steinernema feltiae $(2,000 \mathrm{IJ} / \mathrm{mL})$ and $S$. carpocapsae $(4,000 \mathrm{IJ} / \mathrm{mL})$, with $28.57 \%$, and S. carpocapsae $(2,000 \mathrm{IJ} / \mathrm{mL})$, with $14.29 \%$, caused lower mortality rates than the other strains (Table 1).

The greater virulence of $S$. riobrave can possibly be explained by its ability to move on the soil, by an average of $4 \mathrm{~cm} /$ day, besides its more aggregate distribution pattern (CABANILLAS; RAULSTON, 1994), therefore enabling more infective juveniles to find each host. This characteristic probably explains why the high pathogenicity observed in laboratory was also observed in the greenhouse.

The concentrations did not influence the virulence of the tested EPN strains. A similar result was reported by LeiTe et al. (2007), according to whom $H$. indica (IBCB-n05), applied in concentrations of 5.7 and $22.6 \mathrm{JJ} / \mathrm{cm}^{2}$, did not present any statistical difference, reaching efficiency of $75 \%$ and $85 \%$, respectively, to control Bradysia mabiusi larvae in greenhouse; and 
Table 1. Mortality \pm standard error of Mahanarva spectabilis nymphs caused by strains of entomopathogenic nematodes applied at two concentrations, under greenhouse conditions.

\begin{tabular}{|c|c|c|c|c|c|}
\hline \multirow{2}{*}{ Strain* } & \multicolumn{2}{|c|}{ Concentration ( $\mathrm{IJ} / \mathrm{mL})$} & \multirow{2}{*}{ Total mean } & \multirow{2}{*}{ F value } & \multirow{2}{*}{ p-value } \\
\hline & 2000 & 4000 & & & \\
\hline $\mathrm{Sr}$ & $71.43 \pm 1.84 \mathrm{Aa}$ & $57.14 \pm 2.01 \mathrm{Aa}$ & $64.28 \pm 1.33 \mathrm{~A}$ & 0.84 & 0.3646 \\
\hline Sf & $28.57 \pm 1.84 \mathrm{Ba}$ & $57.14 \pm 2.01 \mathrm{Aa}$ & $42.85 \pm 1.37 \mathrm{~A}$ & 3.36 & 0.0739 \\
\hline RSC 1 & $57.14 \pm 2.01 \mathrm{Aa}$ & $57.14 \pm 2.01 \mathrm{Aa}$ & $57.14 \pm 1.37 \mathrm{~A}$ & 0.84 & 0.3646 \\
\hline Sc & $14.29 \pm 1.43 \mathrm{Ba}$ & $28.57 \pm 1.84 \mathrm{Ba}$ & $21.43 \pm 1.14 \mathrm{~B}$ & 0.80 & 0.3616 \\
\hline Total mean & $42.86 \pm 0.95 a$ & $49.99 \pm 0.96 a$ & - & 0.84 & 0.3646 \\
\hline F value & 5.60 & 1.68 & 5.88 & - & - \\
\hline $\mathrm{p}$-value & 0.0025 & 0.0185 & 0.0019 & - & - \\
\hline
\end{tabular}

Values followed by different capital letters in the columns and small letters in the lines differ from each other by the Tukey test $(p<0.05)$. Sr: S. riobrave; Sf: S. feltiae; RSC 1: H. amazonensis RSC 1; Sc: S. carpocapsae.

by BATisTA et al. (2011), who applied three different concentrations of EPNs on M. fimbriolata in Petri dishes and noticed that this did not influence nymph mortality. The probable explanation is that the lowest concentrated suspension already offered the maximum control these pathogens could attain, so an increased concentration did not significantly increase the control. Therefore, further tests aiming at the control of M. spectabilis can be conducted using $2000 \mathrm{IJ} / \mathrm{mL}$ or less.

After selecting the most virulent strain against $M$. fimbriolata in the laboratory, Leite et al. (2005) tested its efficacy in the field at different concentrations, and found that Heterorhabditis sp. provided a maximum nymph mortality of $70 \%$ against spittlebug, regardless of the tested concentration. In the present study, the nematode of the Heterorhabditis genus was not ranked as the most virulent one, although the strain from this genus showed high virulence in our trial.

Steinernema carpocapsae was the least virulent one. This can be explained by the fact that $M$. spectabilis nymphs do not move long distances, and this nematode species has an ambush foraging strategy, in which infective juveniles adopt a position and wait passively for a host to approach (Lewis et al., 2006). This can also explain the fact that this strain presented good efficiency in the laboratory test, but did not maintain such a performance in the greenhouse, where the IJs had to go in search of the host, even though they were applied directly to the nymph's froth. The other tested strains are either cruiser or intermediate type foragers, which means they actively move around the substrate in search for a host, if necessary.

Steinernema riobrave, $S$. feltiae and $H$. amazonensis $\mathrm{RSC} 1$ were highly virulent, both in the laboratory and in the greenhouse, and can be considered effective for the control of Mahanarva spectabilis, thus confirming the possibility of including them in an integrated pest management programs.

\section{ACKNOWLEDGMENTS}

The first author would like to thank the Insect Pathology Laboratory of Universidade Federal de Lavras for the entomopathogenic nematode strains used in this study; Embrapa Dairy Cattle, for the structure to develop this study; and the Postgraduatr Program in Behavior and Animal Biology of Universidade Federal de Juiz de Fora.

\section{REFERENCES}

BATISTA, E.S.P.; AUAD, A.M. Application methods of entomopathogenic nematodes for control of Mahanarva spectabilis (Hemiptera: Cercopidae). Biocontrol Science and Technology, v.20, p. 1079-1085, 2010.

BATISTA, E.S.P.; AUAD, A.M.; RESENDE, T.T.; MONTEIRO, C.M.O. Screening of entomopathogenic nematodes to control Mahanarva fimbriolata (Hemiptera: Cercopidae). Revista Colombiana de Entomología, v.37, p.198-202, 2011.

CABANILLAS, H.E. Susceptibility of the boll weevil to Steinernema riobrave and other entomopathogenic nematodes. Journal of Invertebrate Pathology, v.82, p.188-197, 2003.
CABANILLAS, H.E.; RAULSTON, J.R. Evaluation of the spatial pattern of Steinernema riobravis in corn plots. Journal of Nematology, v.26, p.25-31, 1994.

GEORGIS, R.; KOPPENHÖFER, A.M.; LACEY, L.A.;BÉLAIR, G.; DUNCAN, L.W.; GREWAL, P.S.; SAMISH, M.; TAN, L.; TORR, P.; VAN TOL, R.W.H.M. Successes and failures in the use of parasitic nematodes for pest control. Biological Control, v.38, p. 103-123, 2006.

GREWAL, P.S.; DENARDO, E.A.B.; AGUILLERA, M.M. Entomopathogenic nematodes: potencial for exploration and use in South America. Neotropical Entomology, v.30, p.191-205, 2001. 
HOLMANN, F.; PECK, D. Economic damage caused by spittlebugs (Homoptera: Cercopidae) in Colombia: A first approximation of impact on animal production in Brachiaria decumbens pastures. Neotropical Entomology, v.31, p.275-284, 2002.

KAYA, H.K.; GAUGLER, R. Entomopathogenic nematodes. Annual Review of Entomology, v.38, p.81-206, 1993.

KAYA, H.K.; STOCK, P. Techniques in insect nematology. In: LACEY, L.A. Manual of Techniques in Insect Pathology. San Diego: Academic Press, 1997. p.281-324.

KOPPENHÖFER, A.M.; COWLES, R.S.; COWLES, E.A.; FUZY, E.M.; BAUMGARTNER, L. Comparison of neonictinoid inseticides as synergists for entomopathogenic nematodes. Biological Control, v.24, p.90-97, 2002

LEITE, L.G.; MACHADO, L.A.; AGUILLERA, M.M.; RODRIGUES, R.C.D.; NEGRISOLI JR, A.S. Pathogenicity of Steinernema and Heterorhabditis (Nematoda: Rhabditidae) against sugarcane root spittlebug nymphs, Mahanarva fimbriolata (Hemiptera: Cercopidae). Revista Agricultura, v.78, p.139-148, 2002.

LEITE, LG.; MACHADO, L.A.; GOULART, R.M.; TAVARES, F.M.; BATISTAFILHO, A. Screening of entomopathogenic nematodes (Nemata: Rhabditida) and the efficiency of Heterorhabditis $s p$. against the sugar cane root spittlebug Mahanarva fimbriolata (Fabr.) (Hemiptera: Cercopidae). Neotropical Entomology, v.34, p.785-790, 2005.

LEITE, L.G.; TAVARES, F.M.; BUSSÓLA, R.A.; AMORIM, D.S.; AMBRÓS, C.M.; HARAKAVA, R. Virulence of entomopathogenic nematodes
(Nemata: Rhabditida) against larva of the fungus gnat Bradysia mabiusi (Lane, 1959) and persistence of Heterorhabditis indica Poinar et al. 1992 on organic substrates. Arquivos do Instituto Biológico, v.74, p.337-342, 2007.

MAULÉON, H.; BARRÉ, N.; PANOMA, S. Pathogenicity of 17 isolates of entomophagous nematodes (Steinernematidae and Heterorhabditidae) for the ticks Amblyomma variegatum (Fabricius), Boophilus microplus (Canestrini) and Boophilus annulatus (Say). Experimental and Applied Acarology, v.17, p.831-838, 1993.

RAMOS-RODRÍGUEZ, O.; CAMPBELL, J.F.; RAMASWAMY, S.B. Efficacy of the entomopathogenic nematode Steinernema riobrave against the stored-product insect pests Tribolium castaneum and Plodia interpunctella. Biological Control, v.40, p. 15-21, 2007.

REIS-MENINI, C.M.R.; PRATA, M.C.A.; FURLONG, J.; SILVA, E.R. Compatibility between the entomopathogenic nematode Steinernema glaseri (Rhabditida: Steinernematidae) and an acaricide in the control of Rhipicephalus (Boophilus) microplus (Acari: Ixodidae). Parasitology Research, v.103, p.1391-1396, 2008

TIAGO, P.V.; SOUZA, H.M.L.; MOYSÉS, J.B.; OLIVEIRA, N.T.; LIMA, E.A.L.A. Differential pathogenicity of Metarhizium anisopliae and the control of the sugarcane root spittlebug Mahanarva fimbriolata. Brazilian Archives of Biology and Technology, v.54, p.435-440, 2011.

WHITE, G.F. A method for obtaining infective nematode larvae from cultures. Science, v.66, p.302-303, 1927. 